$\begin{array}{llr}\text { KULTURA } & \begin{array}{l}\text { POLSKA AKADEMIA NAUK } \\ \text { KOMITET SOCJOLOGI }\end{array} & \begin{array}{r}\text { ISSN 0023-5172 } \\ 2300-195 \mathrm{x}\end{array} \\ \mathbf{i} & \begin{array}{l}\text { INSTYTUT STUDIÓW POLITYCZNYCH } \\ \text { SPOLECENSTWO }\end{array} & \\ 2020, \mathrm{nr} 4 & \end{array}$
$\begin{array}{llllllll}A & R & T & Y & K & U & Ł & Y\end{array}$
I
$\begin{array}{llllllll}\mathrm{R} & \mathrm{O} & \mathrm{Z} & \mathrm{P} & \mathrm{R} & \mathrm{A} & \mathrm{W} & \mathrm{Y}\end{array}$

EMILIA KRAMKOWSKA

Uniwersytet w Białymstoku

\title{
SIMMLOWSKA KONCEPCJA MODY \\ A UBIÓR WSPÓŁCZESNYCH SENIOREK I SENIORÓW \\ PODEJŚCIE BADAWCZE
}

\begin{abstract}
WPROWADZENIE
Moda to pojęcie, które w dyskursie społecznym pojawiło się w XIV wieku na oznaczenie „systemu komunikacyjnego” odnoszącego się do wyglądu człowieka, odpowiadającego konkretnym normom i zasadom panującym w określonym czasie i miejscu (Perchla-Włosik 2019, s. 11). Początków mody można się dopatrywać w praktykach mieszkańców prokapitalistycznych miast włoskich okresu renesansu, wykorzystujących modę do takiego ozdabiania ciała, które odróżniałoby je od wyglądu ciał arystokracji (Kapciak 1999, s. 264). Można więc powiedzieć, że idee odrębności i naśladownictwa, dogłębnie analizowane przez Georga Simmla, od samego początku konstytuują filozofię mody.

Moda to powszechnie przyjęty, a jednocześnie bardzo zmienny sposób stylizowania wyglądu, czyli ubierania się, czesania czy makijażu, popularny w jakimś okresie i/lub miejscu (Linkiewicz 2014). Według Stownika języka polskiego $P W N$ „moda to styl charakterystyczny dla danej epoki, dla określonego terytorium, zespół norm panujących, lansowanych przez pewien czas i dotyczących zewnętrznego wyglądu człowieka (jego ubioru, obuwia, fryzury) czy jego życia" ${ }^{1}$. Przytoczona definicja sygnalizuje wielo-
\end{abstract}

Adres do korespondencji: e.kramkowska@uwb.edu.pl; ORCID: 0000-0002-6420-7014

${ }^{1}$ Mieczysław Szymczak, Stownik jezyka polskiego PWN, Warszawa 1978, s. 501. 
znaczność pojęcia mody, która na przestrzeni wieków przestała być utożsamiana wyłącznie z wyglądem. Modne może być miejsce, sposób spędzania czasu, styl życia, styl muzyczny czy artystyczny. Naukowo rzecz ujmując: „z jednej strony moda może być konkretnym, wytworzonym przemysłowo lub rzemieślniczo przedmiotem okrywającym ludzkie ciało ubiorem, a z drugiej może odnosić się do określonego modelu kulturowego, który obejmuje to co modne, nieustającą zmianę oraz pojawianie się po sobie przedmiotów noszących znamiona nowości i aktualności" (Reckwitz 2017, s. 166). Podobne rozumienie tego terminu spotykamy w języku potocznym - moda zwykle kojarzona jest z krótkotrwałym, a mimo to powszechnym cyklem stylu ubierania się i, co ważniejsze, łączona jest z zachowaniami ludzi młodych. Podłożem takiego stanu rzeczy może być mniej entuzjastyczne nastawienie osób starszych wobec nowości i zmian, będących immanentną cechą mody. Nie można też nie dostrzegać znaczenia zjawiska określanego $\mathrm{w}$ literaturze zagranicznej jako the age-ordering of clothes (Twigg 2007), czyli społecznie zdefiniowanego i „uporządkowanego" sposobu ubierania się reprezentantów poszczególnych grup wieku. Łączenie mody z młodością jest też uwarunkowane historycznie.

Obserwujący świat mody Gilles Lipovetsky dostrzega, że lata sześćdziesiąte XX wieku to początek demokratyzacji mody, czyli przejścia od starego systemu mody (one hundred fashion) traktowanej jako luksus klas wyższych, do fazy mody otwartej (open fashion). Open fashion to moda wymykająca się ograniczającej mocy tradycji, taka, która sprawia, że zamiast uniwersaliów proponowana jest różnorodność. „[...] określone zachowania - pisze Lipovetsky (2008, s. 402) - mogą być determinowane przez przynależność do klas, narodów czy grup wiekowych, oddziaływania te przestają być jednakże wyłączne i jednostronne [...]. Charakterystyczne dla epok tradycyjnych naśladownictwo o charakterze zamkniętym, zostało zastąpione naśladownictwem jednostkowym i częściowym". Open fashion to moda, w której kryterium klasowe nie ma już takiego znaczenia jak dawniej. Liczy się wolność i równość, a podstawową wartością jest jednostka. Zmiana ta związana była z pojawieniem się społecznej roli człowieka młodego, mającej podłoże $\mathrm{w}$ wydarzeniach lat sześćdziesiątych obserwowanych w Stanach Zjednoczonych oraz w wielu krajach Europy Zachodniej ${ }^{2}$. Oprócz wojny w Wietnamie i towarzyszących jej protestów antywojennych kluczowe znaczenie miała wówczas rewolucja seksualna

\footnotetext{
${ }^{2} \mathrm{Na}$ przykład w Wielkiej Brytanii rozmaite subkultury Londynu, obejmujące przede wszystkim młodzież i młodych dorosłych, zaczęły wzorować się na modzie ulicznej (street style). Ta indywidualistyczna i eksperymentalna moda traktowana była jako sprzeciw wobec
} 
oraz powstanie i rozwój subkultury hippisowskiej określającej się jako ruch młodzieżowy. Hippisi stali się ucieleśnieniem buntu młodych przeciwko światu dorosłych, wraz z jego instytucjami, normami i zakazami. Rola człowieka młodego, wcześniej oparta na kryterium wieku, z czasem „stała się synonimem nowego wzoru konsumpcji, w tym konsumpcji związanej z ubiorem. Młody człowiek miał przede wszystkim wyglądać młodo i czuć się młodo. Osiągnięcie młodego wyglądu stało się najważniejszym celem ubioru” (Dowgiałło 2015, s. 26). Wydaje się, że po dziś dzień „bycie modnym oznacza bycie młodym, a bycie młodym to bycie zmiennym" (Braunstein, Doyle 2002, s. 24).

Świat mody nie jest jedynym obszarem, w którym obserwujemy współczesne zorientowanie na młodość. Jest to zjawisko o zdecydowanie szerszym zasięgu. Zauważa to Anthony Giddens i nazywa dzisiejsze społeczeństwo „młodniejącym” (,youthing” society), przez co rozumie „społeczeństwo, w którym zwyczaje i zachowania osób starszych są zbieżne ze zwyczajami i zachowaniami młodszego pokolenia" (Giddens 2009, s. 170). $\mathrm{Z}$ jednej strony demografowie biją na alarm i przestrzegają przed następstwami postępującego procesu starzenia się społeczeństw Europy, z drugiej zaś szerząca się dziś juwenalizacja kultury skłania do dyscyplinowania starości, podporządkowania jej nowym normom, zgodnie z którymi między innymi sposób ubierania się, czesania czy makijaż odgrywają kluczową rolę w oznaczeniu prestiżu społecznego jednostki - jej wygląd oceniany jest w odniesieniu do współczesnego kanonu piękna - ciała młodego i harmonijnego. Kult i aktywność młodości proponowane są jako sposób egzystencji współczesnego człowieka (Rejakowa 2010, s. 16). W związku $z$ tym udane starzenie się coraz bardziej interpretowane jest jako starzenie się bez pokazywania starości. Starość należy odmłodzić, wiek metrykalny - ukryć. Nietrudno zauważyć, że wiele osób starszych realizuje te „zalecenia" i praktykuje zachowania, które mają odmłodzić wygląd ich ciała. Przejawia się to między innymi w sferze ubioru.

Zagadnienie mody i ubioru ludzi starych w kontekście starzenia się społeczeństw od wielu lat analizuje Julia Twigg. Zwraca uwagę na funkcjonujący $\mathrm{w}$ każdym społeczeństwie the age-ordering of clothes, który wyznacza również sposób ubierania się seniorów. Zgodnie z nim, zdaniem autorki, osoby w starszym wieku powinny nosić dłuższe i mniej kształtne elementy garderoby, mniejsze dekolty, ubrania o ciemniejszej kolorystyce, co czyni je niejako niewidzialnymi w przestrzeni społecznej (Twigg 2013;

haute couture, czyli mody ekskluzywnej, tworzonej na zamówienie i w związku z tym będącej narzędziem zaznaczania różnic społecznych (Reckwitz 2017, s. 167). 
Gibson 2000; Greer 1991). Marginalizacja seniorów jest też jedną z przyczyn niedostatecznego rozpoznania zagadnienia ich ubioru $\mathrm{w}$ literaturze socjologicznej czy gerontologicznej. Inny powód to między innymi przekonanie, że moda podkreśla atrakcyjność fizyczną czy seksualność człowieka, a nieliczni postrzegali/postrzegają ciało seniora $z$ tej perspektywy. Jednak zwiększanie się populacji osób starszych spowodowało, że stała się ona bardziej widoczna w przestrzeni społecznej, także pod względem ubioru, co wiąże się ze wzrostem zainteresowania modą. Nie bez znaczenia jest też, zdaniem Chrisa Gillearda i Paula Higgsa (2000), analizowanie starości w kontekście konsumpcji, aktywności społecznej czy osobistego rozwoju. W rezultacie czynniki decydujące o dokonywanych przez ludzi starych wyborach konkretnych elementów garderoby są przedmiotem naukowych poszukiwań (Williams, Sołtysiak 2016; Twigg 2007; 2013; Slevin 2010; Szarota 2008; Szlendak, Pietrowicz 2007). Co w tym zakresie udało się ustalić? Niestety niewiele, gdyż jak dotąd - zwłaszcza w nauce polskiej - jest to temat niszowy. Dostępne opracowania posłużą tu jako punkt odniesienia w dyskusji wyników zaprezentowanych dalej badań własnych.

We wstępie do jednej ze swoich książek Julia Twigg $(2013$, s. 3) napisała: „[...] moda i starość czują się niekomfortowo w swoim towarzystwie. Moda zamieszkuje świat młodzieńczego piękna, fantazyjnej wyobraźni, powabu. Jej dyskursy są szaleńcze, wizerunki pełne blasku i - przede wszystkim - młodzieńcze. Starość z kolei postrzegana jest jako czas szarości, naznaczony «rozbratem» z modą, związany ze stonowaną, samonapędzającą się nieefektowną prezencją. [...] Z perspektywy świata mody starość jest peryferyjna i zaprzecza centralnym wartościom mody, gdyż ząb czasu niszczy młodzieńcze piękno, które moda chce podkreślać". Stanowisko autorki skłania do zastanowienia. Badaczka analizuje zagadnienie mody i ubioru seniorów na podstawie badań i obserwacji prowadzonych wśród osób starszych w Wielkiej Brytanii. Uznałam, że interesującym będzie sprawdzenie, czy wysuwane przez nią wnioski pasują do sytuacji polskich seniorów.

Postanowiłam przyjrzeć się ubiorowi osób starszych — kobiet i mężczyzn. Na podstawie badań przeprowadzonych wśród osób w wieku 60 lat i więcej poszukiwałam odpowiedzi na następujące pytania: Co na temat sposobu ubierania się dzisiejszych seniorów sądzą osoby starsze? Czy ich zdaniem podążają za modą rozumianą jako naśladownictwo albo narzędzie służące pokazaniu swej odrębności? Co w opinii badanych warunkuje sposób ubierania się współczesnych seniorów? Zagadnienia te analizuję z uwzględnieniem płci badanych, a punkt wyjścia przedstawionych rozważań stanowi Simmlowska koncepcja mody. 


\section{GEORG SIMMEL I JEGO FILOZOFIA MODY}

Zaproponowana przez Georga Simmla koncepcja mody zwraca uwagę na kilka jej specyficznych przymiotów. Po pierwsze - autor traktował modę jako formę uspołecznienia. Po drugie - analizowane przez niego idee naśladownictwa i odrębności, będące immanentną właściwością mody, stały się podstawą teorii trickle down.

Myśl socjologiczna Simmla to odniesienie do zjawiska wzajemnego oddziaływania opartego na regule panrelacyjności, zgodnie z którą wszystko wchodzi w relację ze wszystkim. „Dla Simmla rzeczywistość jako taka ma przede wszystkim charakter relacyjny, stąd pojęciami kluczowymi w jego socjologii są interakcja i uspołecznienie" (Dowgiałło 2015, s. 46). Analizując interakcje Simmel zwracał uwagę na ich formę, czyli na zobiektywizowane wzory wzajemnego oddziaływania na siebie jednostek, obok elementów spontaniczności stanowiące podstawę interakcji (Szacki 2003, s. 451). Podążając tym tropem Simmel bez większych trudności połączył modę $z$ uspołecznieniem dostrzeganym w sposobie ubierania się jednostek. Pojmowanie mody jako formy uspołecznienia to wskazanie, że jest ona „wzorem interakcji, która charakteryzuje się dynamiką wynikającą z poszukiwania równowagi między upodobnieniem i odróżnieniem, gdzie upodobnienie symbolizuje aspekt społeczny, a odróżnienie aspekt jednostkowy" (Dowgiałło 2015, s. 57). Zdaniem Simmla naśladownictwo i odrębność są naturalnie wpisane w system mody. I to on jako pierwszy w pełni rozpoznał, zrozumiał i opisał ową złożoność dialektycznej relacji między wspomnianymi aspektami mody i jej ambiwalentną naturę.

„Moda to naśladownictwo danego przykładu, zaspokajające pragnienie adaptacji społecznej: wiedzie jednostkę drogą, którą podróżują wszyscy. [...] Zarazem w mniejszym stopniu zaspokaja pragnienie różnicowania, tendencję ku odmienności, pragnienie zmiany i przeciwieństwa [...]. Moda stanowi po prostu jedną z wielu form życia, za pomocą których staramy się połączyć w jednolitej sferze działalności tendencję ku społecznemu ujednolicaniu i pragnienie jednostkowego odróżniania się i zmiany" (Simmel 2007a, s. 273). Naśladownictwo uwalnia człowieka od konieczności podejmowania decyzji i od estetycznej odpowiedzialności za ich skutki, pokazując konkretny sposób ubierania się, zachowania, określone sądy czy cały styl życia, w którym wyraża się człowiek. Negatywną stroną tej własności mody jest jej zdolność do sprawowania władzy. Moda „wprowadza niezwykle silny system znaków, który decyduje o całokształcie zachowań społecznych" (Linkiewicz 2014, s. 281), w niektórych przypadkach stając się nawet źródłem opresji. Zależność tę dostrzegł Simmel (2007a, s. 272): 
„moda jest społeczną formą, która - podobnie jak prawo — dotyczy zewnętrznych aspektów życia, tylko tych jego stron, które zwrócone są ku społeczeństwu. Dostarcza nam formuły, dzięki której można zaświadczyć naszą zależność od czegoś, co jest ogólnie przyjęte, nasze posłuszeństwo normom narzuconym przez epokę".

Jednak moda jest też narzędziem, za pomocą którego jednostka może ujawnić tkwiącą $\mathrm{w}$ niej potrzebę wyrażenia swej indywidualności, autonomii zachowania czy wyróżnienia się z ogółu, na przykład poprzez zastosowanie oryginalnego połączenia elementów garderoby. W takiej sytuacji moda może posłużyć ucieleśnieniu tożsamości. W jednym ze swoich esejów Simmel (2008, s. 432 stwierdził): „Społeczeństwo składa się z istot, które tylko po części są istotami społecznymi, co więcej, z istot, które z jednej strony postrzegają siebie jako egzystencje w pełni społeczne, $z$ drugiej strony, przy tej samej treści, jako egzystencje w pełni osobiste”. W innym miejscu konstatował: „moda jest taką formą życia, która ma zapewnić kompromis między tendencją do społecznego zrównania a tendencją do indywidualnej odrębności” (Simmel 2006, s. 22). „Każdy typ uspołecznienia - pisał - powinien utrzymać równowagę między potrzebą indywidualizacji a potrzebą socjalizacji, niezależnie od różnic treści i formy, jakie te potrzeby mogą przybierać" (Simmel 2005, s. 264). A zatem dwie tendencje społeczne - potrzeba jedności i potrzeba izolacji - są w koncepcji Simmla traktowane jako istotne dla ustanowienia mody, wręcz z nią nierozłączne. „Jeżeli jednej z nich zabraknie, moda nie powstanie, albo jej panowanie skończy się gwałtownie" (Simmel 2007a, s. 275).

Idee naśladownictwa i odrębności zarysowane w Simmlowskiej koncepcji mody dały początek teorii trickle down, czyli przenikania mody z góry na dół. „Według tej koncepcji moda «skapuje» w dół drabiny społecznej, ponieważ klasy niższe naśladują modę klas wyższych. Kiedy klasy te, chcąc podwyższyć swój status, przejmują modę góry drabiny społecznej, klasy wyższe, pragnąc $z$ kolei utrzymać swój status, zwracają się ku nowej modzie, dzięki której upodobnienie obu klas staje się niemożliwe" (Dowgiałło 2015, s. 24). Teoria Simmla może stanowić wytłumaczenie mechanizmu mody i jest pomocna w przewidywaniu jej cykli. Moda zmienia się wówczas, gdy style klasy wyższej i niższej stają się do siebie bardzo podobne (Perchla-Włosik 2019, s. 16).

Bogna Dowgiałło (2015, s. 58) zauważa, że sam Simmel nie używał określenia trickle down. Chociażby angielska, a nie niemiecka, nazwa nadana jego spostrzeżeniom może świadczyć o tym, że określenie to zawdzięczamy interpretatorom jego koncepcji. Trzeba też zaznaczyć, że klasyczna koncepcja Simmla podlegała wielu rewizjomi, gdyż zmiany społeczne 
obserwowane na przełomie XX i XXI wieku spowodowały konieczność przemyślenia poszczególnych kwestii, zwłaszcza tych dotyczących kierunku przepływu mody. Na przykład Herbert Blumer (1969) nie zgadzał się z tezą Simmla dotyczącą wertykalnego przenikania mody - jego zdaniem przynależność do klasy społecznej nie determinuje bycia modnym lub niemodnym. „W dobie kultury masowej moda dociera równocześnie do przedstawicieli wszystkich klas społecznych i nie można jej traktować jako pochodnej podziałów opartych na kryterium klasowym. Ludzie przyjmują daną modę nie dlatego, że chcą naśladować klasy wyższe, ale dlatego, że moda im się podoba" (Dowgiałło 2015, s. 38). Podobnego zdania był Fred Davis, który zaproponował, by analiza zjawiska mody uwzględniała zwykłych ludzi, którym często odmawia się roli „modowych innowatorów". Twierdził, że moda i styl ubioru nie oznaczają tego samego dla wszystkich członków społeczeństwa, a dyfuzja mody jest wielokierunkowa. Przyjęcie wertykalnego modelu jest znacznym uproszczeniem, którego nie da się obronić mniej więcej od lat sześćdziesiątych XX wieku, czyli od fazy open fashion (Davis 1989, s. 200-220). Dokonujące się zmiany przyczyniły się do wypracowania koncepcji bublle-up, czyli przenikania mody w górę drabiny społecznej, o czym czytamy w opracowaniach Teda Polhemusa. Jego zdaniem wielcy projektanci podpatrują stylizacje modowe przedstawicieli niższych grup społeczno-ekonomicznych, które następnie popularyzują wśród klasy wyższej (Polhemus 1994). Dotyczy to na przyklad stylizacji subkultur młodzieżowych czy muzycznych. „Style, które rozpoczęły swoje życie na ulicy, mogą w końcowym etapie znaleźć się na największych wybiegach, noszone przez top-modelki, a przedmioty będące niegdyś subkulturowymi emblematami stają się główną modową alternatywą dla wszystkich" (Perchla-Włosik 2019, s. 22). Model bublle-up jest zatem przeciwieństwem teorii trickle down.

Dla przedstawionych tu rozważań ważne jest, by zaznaczyć, że oprócz kontekstu stratyfikacji społecznej, w którym Simmel osadził idee naśladownictwa i odrębności, modę wiązał on również z płcią. Uważał mianowicie, że naśladownictwo w modzie, czyli podążanie za normami określonymi przez epokę, jest praktykowane przede wszystkim przez kobiety. „Jeśli moda - pisał Simmel (2007b, s. 11) — wyraża i jednocześnie akcentuje popęd egalitarystyczny i indywidualistyczny, powab naśladownictwa i chęci odznaczenia się, wówczas być może wyjaśnia to, dlaczego kobiety $\mathrm{w}$ ogóle $\mathrm{z}$ tak szczególną mocą ulegają modzie. Ze słabości pozycji społecznej, na którą kobiety były skazane w nad wyraz przeważającej części dziejów, wynika ich ścisłe przywiązanie do tego, co jest «obyczajem», do tego, "co uchodzi», do powszechnie uznawanej i akceptowanej formy 
istnienia. Słaby bowiem unika indywidualizacji, [...] tylko typowa forma życia gwarantuje mu ochronę, która silnemu przeszkadza w wykorzystywaniu jego wyjątkowych sił".

Zacytowany fragment pokazuje, jak się wydaje, w jaki sposób moda może sprawować władzę nad człowiekiem, a konkretnie nad kobietą i jej ciałem. Ze względu na słabość pozycji społecznej przestrzega ona norm społecznych w zakresie mody i nie tylko. Dalej Simmel (2007b, s. 12-13) pisze: „Jednak na utrwalonym gruncie obyczaju, przeciętności, powszechnego poziomu kobiety dążą też do możliwej, względnej indywidualizacji i zaakcentowania własnej osobowości. Moda oferuje im tę kombinację. [...] Moda jest jakby wentylem, z którego uchodzić będzie kobieca potrzeba pewnego odznaczenia się oraz indywidualnego zaakcentowania, gdy na innych obszarach nie będzie jej dane znaleźć możliwości zaspokojenia. [...] Mężczyzna w mniejszym stopniu będzie potrzebował tych zewnętrznych form urozmaicenia. Tak właśnie obojętność na mody zewnętrznego wyglądu są cechami specyficznie męskimi nie dlatego, że mężczyzna jest istotą bardziej jednolitą, ale dlatego, że jest kimś bardziej wszechstronnym". Jak zauważa Andreas Reckwitz (2017, s. 167-168): „mimo że konkretny styl lub ubranie dzięki projektantowi-artyście zmierza ku estetycznej wyjątkowości, decydująca się na nie kobieta w dużej mierze dokonuje tym samym kulturowej dystynkcji”. Nawiasem mówiąc, świat mody często kreowany jest przez mężczyzn (projektantów).

Podporządkowywanie się normom społecznym, zwłaszcza tym dotyczącym mody, a więc wyglądu, ubioru, zachowania, zdaniem Simmla częściej przynależy kobietom niż mężczyznom. Jeśli zaś zdarza się kobietom wykorzystywać modę jako narzędzie do pokazania swej odrębności, to dzieje się tak wówczas, gdy nie są w stanie uczynić tego na innych płaszczyznach. Wszechstronny mężczyzna ma w tym zakresie większą swobodę i dowolność, a nawet jeśli podąża za modą, wykorzystuje to na rzecz wzmocnienia własnej pozycji. Simmel (2007b, s. 13) pisze: „Z jednej strony mężczyzna, który w stan zawodowy wrasta, włącza się w sferę względnego upodobnienia, w obrębie swojego stanu jest równy wielu innym osobnikom, często jest egzemplifikacją pojęcia swego stanu lub zawodu. $\mathrm{Z}$ drugiej i jakby $\mathrm{w}$ rekompensacie za to zdobi go pełnia znaczenia, rzeczowa i społeczna siła jego stanu, a do jego znaczenia indywidualnego jest dodane jego znaczenie społeczne". Być może dlatego moda, sposób ubierania się czy wygląd częściej analizowane są w odniesieniu do kobiet. To one regularnie kupują ubrania, wydają na nie więcej pieniędzy i to ich aparycja częściej jest przedmiotem uwagi i komentarzy niż wygląd mężczyzny — choć przyznać należy, że ostatnimi czasy to się zmienia. Wydaje się jed- 
nak, że „dążenie do uzyskania fizycznego piękna było zawsze i wciąż jest źródłem konstruktywnego dla tożsamości kobiety i odrębnego dla niej w porównaniu z mężczyzną — doświadczenia biograficznego [...]. Wygląd kobiety stanowi zawsze podstawowy, wyjściowy wyznacznik identyfikacji. Jest ekspresją nieodwołanych oczekiwań, narzucanych ciału kobiety przez obowiązujące standardy i normy społeczne" (Gromkowska-Melosik 2013, s. 63). I niezależnie od tego, czy rzecz dotyczy kobiet młodych czy starych, każda $z$ nich powinna uosabiać wzory piękna określone owymi standardami. Pomagają $\mathrm{w}$ tym przeróżne praktyki społeczne, a moda i medycyna odgrywają kluczową rolę w społecznym manipulowaniu ciałem kobiecym, „stanowiąc - zdaniem Agnieszki Gromkowskiej-Melosik (2012, s. 18) podstawową strategię $\mathrm{w}$ potwierdzaniu asymetrycznych stosunków między kobietami i mężczyznami, zawsze na niekorzyść tych pierwszych". Podobnego zdania jest Sheila Jeffreys (2005), według której moda zawsze była postrzegana jako narzucanie opresyjnych form tożsamości płciowej czy ucieleśnienie praktyk mających na celu uprzedmiotowienie i ograniczenie kobiet, a nawet zamknięcie ich w defensywnych i nieautentycznych formach prezentacji. Uznałam więc, że zagadnienie mody i ubioru seniorów warto rozpatrywać nie tylko w odniesieniu do wieku, ale też płci.

Simone de Beauvoir (2003) analizując sytuację kobiet stwierdziła, że w kulturze patriarchalnej nie ma miejsca na mądrość i intelekt kobiet. Kulturowa koncepcja płci zakłada, że pozycja społeczna mężczyzny jest podyktowana jego intelektem i osiągnięciami, na przykład zawodowymi, a pozycja społeczna kobiety w dużej mierze zależy od jej wyglądu. Pułapka patriarchatu wydaje się najokrutniejsza w stosunku do kobiet w wieku podeszłym. „Stara, mądra kobieta nie budzi podziwu, lecz lęk. A gdy próbuje uciec od swego wieku i przypisanej mu niewidoczności starzejącego się kobiecego ciała - staje się śmieszna" (Gajewska 2008, s. 268). Mocne słowa. Czy faktycznie tak jest? Czy strach kobiet przed starością popycha je do śmiesznych (w ocenie innych) zachowań? „Moda - pisał Simmel (2007b, s. 13) - stanowi dla kobiet $\mathrm{w}$ pewnym sensie element zastępczy pozycji w danym zawodzie". Starsze kobiety etap aktywności zawodowej mają już za sobą. Czy zatem spostrzeżenia Simmla są szczególnie trafne w odniesieniu do ich sytuacji? Czy w ich przypadku moda, a konkretnie sfera ubioru służy jako narzędzie upodobnienia się czy może zaakcentowania indywidualności?

\section{METODOLOGIA BADANIA}

Badania, które tu przedstawiam, przeprowadziłam w czerwcu-listopadzie 2019 roku wśród osób w wieku 60 lat i więcej. Na początku posłu- 
żyłam się strategią ilościową, sięgnęłam po metodę sondażu diagnostycznego, a wybraną techniką była ankieta rozdawana pt. „Nasze ubrania”, składająca się $z$ piętnastu pytań. W drugim etapie zastosowałam strategię jakościową - przeprowadziłam wywiady swobodne z osobami, które wyraziły na to zgodę.

O wypełnienie ankiety poprosiłam uczestników projektu Akademia Trzeciego Wieku, który jest realizowany na Uniwersytecie w Białymstoku od marca 2019 roku. Ma on umożliwić osobom starszym, zwłaszcza tym, które dotychczas nie miały takiej szansy, udział w działaniach edukacyjnych. Seniorzy, uczęszczając na warsztaty i wykłady, wzbogacają swą wiedzę, doskonalą umiejętności, co powinno zapobiec ich wykluczeniu w różnych sferach. Podczas prowadzonych przeze mnie warsztatów zaproponowałam uczestnikom wypełnienie ankiety oraz poinformowałam o planowanym drugim etapie badań (wywiady), prosząc, by chętni do rozmowy zgłosili się do mnie indywidualnie w celu ustalenia dogodnego terminu spotkania.

W sumie zgromadziłam 134 ankiety. Wśród ankietowanych dominowały seniorki (67,2\%), mężczyźni stanowili blisko $1 / 3$ (32,8\%). Najliczniejszą grupą były osoby w wieku 60-69 lat (49,3\%), nieco starszych (70-79 lat) było 42,5\%, a liczących 80 lat i więcej $8,2 \%$ ankietowanych. Dominowały osoby z wykształceniem wyższym (47\%), a 37,3\% wskazało na ukończenie szkoły średniej. Blisko połowa $(47,8 \%)$ seniorów oceniła stan swego zdrowia jako dobry, a 44,7\% jako przeciętny. Bardzo dobrą kondycję zdrowotną zadeklarowało 7,5\% osób. Gotowość udziału w drugim etapie badań wyraziły 22 osoby (15 kobiet i 7 mężczyzn). Najmłodsza narratorka miała 63 lata, najstarsza - 90. Blisko połowę narratorów (10/22) stanowiły osoby w wieku 60-69 lat, 7 osób należało do grupy wiekowej 70-79 lat, a pozostali rozmówcy mieli 80 lat i więcej. Wszyscy ocenili stan swego zdrowia jako dobry.

Podstawową zmienną, którą uwzgledniam w rozważaniach, jest płeć (K - kobieta; $\mathrm{M}$ - mężczyzna) moich respondentów i narratorów. Prezentowane badania traktuję jako badania wstępne i przygotowanie do dalszej diagnozy o zasięgu ogólnopolskim.

\section{(MODNE) UBIERANIE SIĘ WSPÓŁCZESNYCH SENIOREK I SENIORÓW W OCENIE BADANYCH}

Teoretycy mody, w tym Simmel, udowadniają, że moda łączy atrakcyjność zmiany i urok odróżniania się z pragnieniem konformizmu i dopasowania się do reszty. Moda też, co równie istotne, kształtuje zasób wiedzy 
o tym, co w danej chwili jest wartościowe i za czym warto podążać (Twigg 2013). Tylko czy to, co jest wartościowe dla młodszych generacji, jest też takim dla osób starszych?

Zapytałam respondentów, co podoba i nie podoba się im w tym, jak ubierają się dzisiejsze kobiety-seniorki i dzisiejsi mężczyźni-seniorzy?

Zacznijmy od ubioru kobiet (wykres 1). Wszystkie osoby badane odpowiedziały, że u współczesnej seniorki lubią schludność, czystość i dbałość o wygląd. Na drugim miejscu pojawił się dobry gust, stosowność ubrania do okoliczności (K: 94,4\%; M: 91,2\%), a trzecią co do częstości wskazań była odpowiedź: swoboda wyboru ubrania (M: 93,2\%; K: 92,2\%). Niemal identyczny był stosunek kobiet i mężczyzn do odpowiedzi „elegancja, kla-

Wykres 1

Co się Panu(i) podoba w tym, jak dzisiaj ubierają się kobiety-seniorki? (w \%)

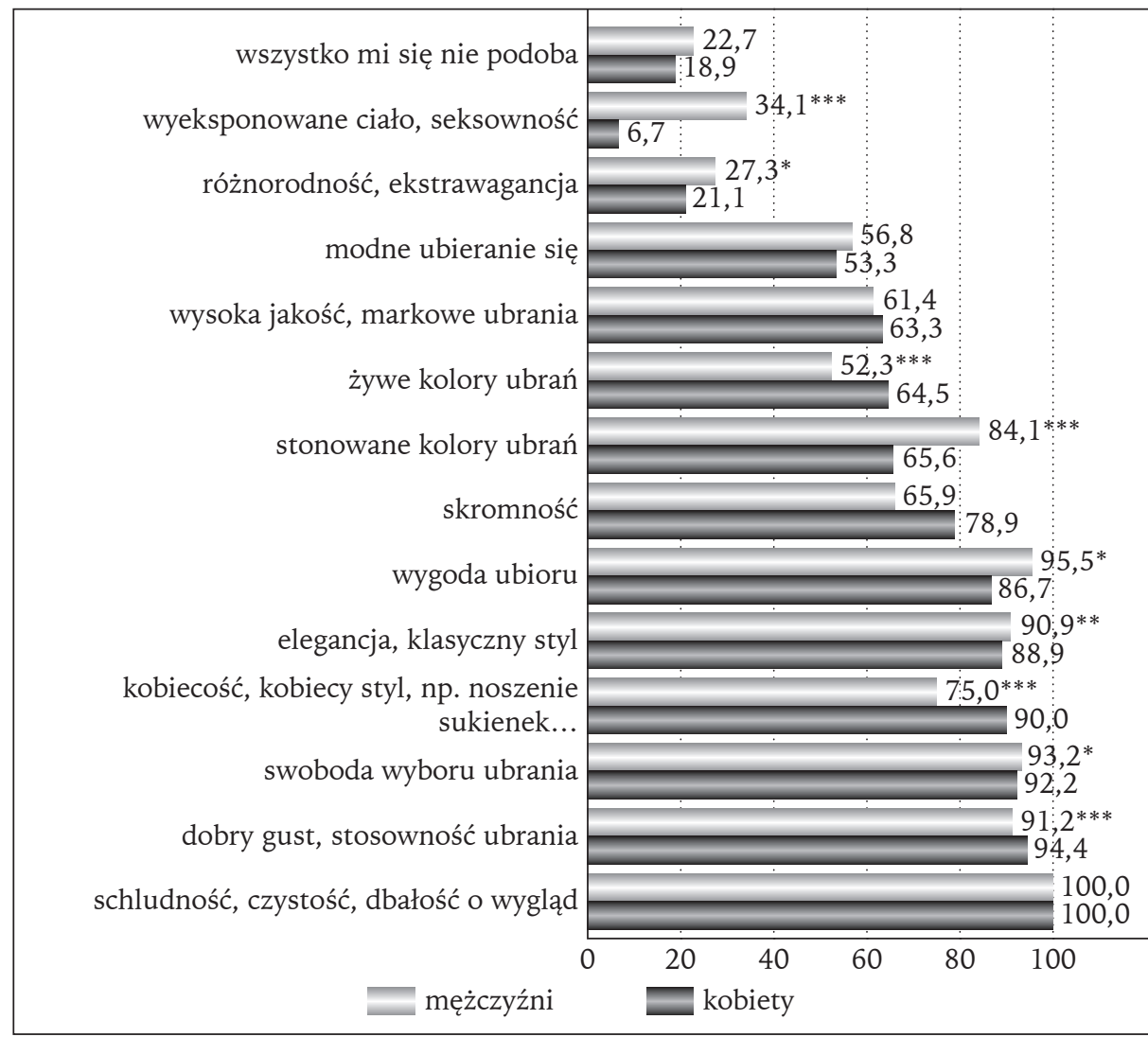

${ }^{*} \mathrm{p}<0,05$

$$
{ }^{* *} \mathrm{p}<0,01
$$$$
* * * \mathrm{p}<0,001
$$

Źródło: badania własne. 
syczny styl". Jednakże seniorkom zdecydowanie częściej niż seniorom podoba się u rówieśniczek kobiecy styl ubioru, czyli noszenie sukienek, spódnic (K: 90\%; M: 75\%), jego skromność (K: 78,9\%; M: 65,9\%), żywe kolory garderoby (K: 64,5\%; M: 52,3\%). Z kolei badanym mężczyznom zdecydowanie częściej niż kobietom w stroju rówieśniczek odpowiada wygoda ubioru (M: 95,5\%; K: 86,7\%), stonowane kolory ubrań (M: 84,1\%; K: 65,6\%), a nawet wyeksponowane ciało, seksowność ubioru (M: 34,1\%; K: 6,7\%).

Piotr Szarota, analizując psychologię stroju mieszkańców powojennej Polski, tak opisuje stare kobiety: „Kobiety przestają dbać o swój wygląd, higienę i mieszkanie [...]. Potrafią całymi dniami siedzieć przy oknie, słuchać radia bądź wpatrywać się w telewizor. Nie dla starych jest wyjście do kina, nie dla starych też ładny wygląd w myśl przysłowia Stary nie stoi o modę, ale o wygodę. Zwracają uwagę na praktyczność stroju. Musi być wygodny, ciepły i koniecznie w ciemnym kolorze" (Szarota 2008, s. 166-167).

Zacytowany fragment może pomóc $w$ interpretacji opinii osób badanych. Po pierwsze - przytoczone przez Szarotę przysłowie wydaje się wciąż aktualne, o czym można wnioskować ze wskazań badanych mężczyzn, choć kobiet również. Po drugie - kolorystyka ubrań. Częściej wyrażaną przez starszych mężczyzn preferencję dla nierzucających się w oczy kolorów odzienia można potraktować jako przejaw ich zachowawczej postawy i „ukłon” w stronę społecznie określonego porządku ubioru i tradycyjnego wizerunku osoby w podeszłym wieku, którą powinna cechować powaga. Ciemna kolorystyka ubrań może być w tym zakresie pomocna.

Kiedy zapytałam osoby biorące udział $\mathrm{w}$ drugim etapie badań (czyli w wywiadach) o ich opinie na temat kolorów ubrań noszonych przez współczesnych seniorów jedna $z$ kobiet powiedziała:

Kiedyśstarsze osoby bardziej preferowały czerń, brazy, odcienie szarości. Takie smutne kolory. Ale zauważyłam, że teraz sa żótcie, czy kolorowe kwiaty, latem sukienki, topiki w takie tączki, teraz bardziej kolorowo $[\mathrm{K}, 71]^{3}$.

Albo komentarz innej kobiety:

Uważam, że seniorzy nosza wszystkie kolory ubrań, ale w bardziej spokojnych odcieniach, czyli nie takich krzykliwych $i w$ oczy to nie kole, czyli róż nie jakiś tam krzykliwy, ale bardziej zgaszony, albo czerwień... Przecież to też ludziom starym pasuje [K, 75].

Warto zacytować wypowiedź jeszcze jednej narratorki, która komentując kolorystykę ubrań seniorów, odniosła się do czasów PRL-u:

3 Oznakowanie fragmentów cytowanych wywiadów jest następujące: K (kobieta), M (mężczyzna), po przecinku został podany wiek rozmówcy. 
Jak byliśmy za żelazną kurtyna to by to tylko szaro i brazowo. Tak się ubierali seniorzy jak byłam młoda, takie smutne ubrania. Po wojnie nic nie było, szare, bure, smutne jak ja to mówię, ale to dlatego, że nie byto konfekcji, nie było produkcji materiałów tak jak dziś, kolorowych. Byt czarny kolor, brazowy i szary i jeszcze jakiś taki kawa $z$ mlekiem czy coś takiego. To takie byty kolory. W latach sześćdziesiatych powoli zaczynato się to zmieniać [K, 88].

Wydaje się zatem, że część seniorów, głównie seniorek, kupowanie i noszenie kolorowych, a więc także modnych ubrań może traktować jako „nadrabianie” minionych lat naznaczonych „brakiem wszystkiego”. Teraz można korzystać z tego, co oferuje kultura konsumpcyjna, i wydaje się, że seniorki są bardziej otwarte na trendy mody. Czy ich zachowanie można uznać za egzemplifikację Simmlowskiej idei naśladownictwa? Niewykluczone, że tak. Pomocnym w zajęciu stanowiska w tej sprawie może być następujący komentarz jednego z mężczyzn:

Wyjazdy za granice dużo daty $i$ wejście Polski do Unii. Ludzie zaczęli więcej podróżować $i$ podgladali jak $i$ co $i$ wprowadzali u siebie to co tam zobaczyli. I to udzielato się też osobom starszym [M, 66].

Na wykresie 1 zauważalna jest także różnica w podejściu kobiet i mężczyzn do seksownego wyglądu i wyeksponowanego ciała kobiety. Badani wypowiadali się na temat ubioru starszych kobiet, ale nie można wykluczyć, że męskie oko wciąż „szacuje” ciało kobiece pod względem fizycznej atrakcyjności i związanej z nią zmysłowości.

A co sądzą badani na temat ubioru współczesnego mężczyzny w starszym wieku? (wykres 2). W niemal identyczny sposób badane kobiety i mężczyźni odbierają dobry gust i stosowność ubrania rówieśnika, praktykowaną przez niego wygodę ubioru czy sportowy styl. W pozostałych kwestiach pojawiają się różnice. Kobietom bardziej niż mężczyznom odpowiada schludność, czystość i dbałość o wygląd współczesnego seniora (K: 100\%; M: 95,5\%), jego elegancja i klasyczny styl (K: 86,7\%; M: 81,8\%); noszenie garniturów, koszul i krawatów (K: 78,9\%; M: 70,5\%), skromność (K: 74,4\%; M: 65,9\%), modne ubieranie się (K: 57,8\%; M: 52,3\%), kobiety też $(47,8 \%)$ są zdecydowanie większymi zwolenniczkami żywych kolorów ubrań niż mężczyźni (20,5\%). W sposobie „noszenia się” rówieśników badanym mężczyznom częściej niż kobietom podoba się swoboda wyboru ubrania (M: 90,9\%; K: 85,6\%) i stonowane kolory poszczególnych elementów garderoby (M: 70,5\%; K: 65,6\%). Seniorzy (50\%) bardziej niż seniorki $(41,1 \%)$ zwracają też uwagę na wysoką jakość odzieży / noszenie markowych ubrań i niemal dziesięciokrotnie częściej niż seniorkom podoba się im ubiór eksponujący męskie (np. umięśnione) ciało. 
Wykres 2

Co się Panu(i) podoba w tym, jak dzisiaj ubierają się mężczyźni-seniorzy? (w \%)

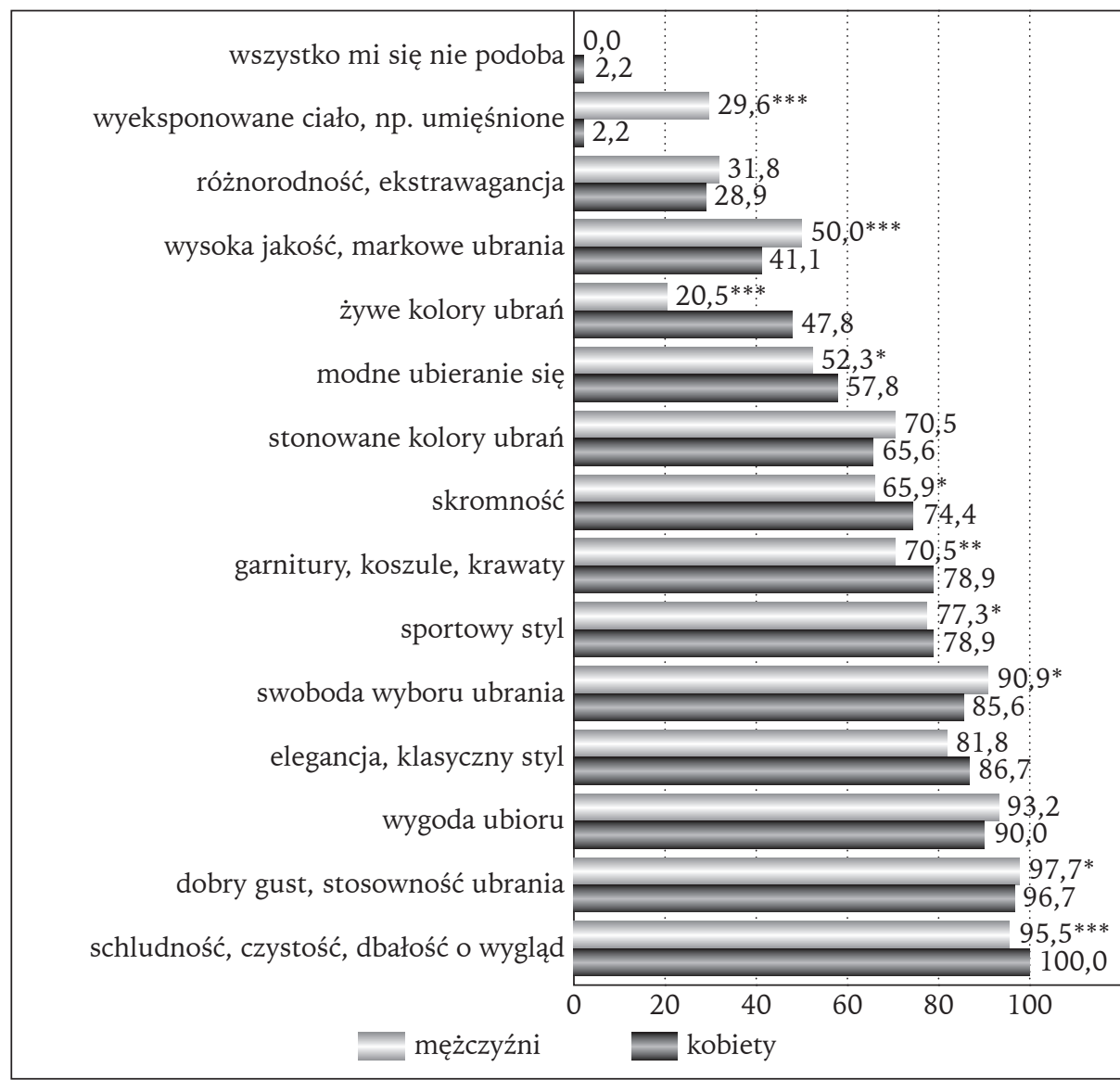

${ }^{*} \mathrm{p}<0,05$

${ }^{* *} \mathrm{p}<0,01$

$* * * \mathrm{p}<0,001$

Źródło: badania własne.

Beata Łaciak (2006, s. 74) uważa, że w czasach PRL-u cechy takie jak piękno, urok czy elegancja nie były wzorcami społecznymi w zakresie cielesności. Dbałość o wygląd oznaczała przede wszystkim higienę i codzienne mycie całego ciała. Tego właśnie zostało nauczone w młodości dzisiejsze pokolenie seniorów. Opinia autorki może stanowić wyjaśnienie preferencji respondentów dla schludnego, czystego wyglądu i ubioru ich rówieśników. Po transformacji ustrojowej w 1989 roku i wynikających z niej zmianach w polskiej rzeczywistości pojawiły się nowe możliwości dbania o ciało i wygląd, co obecnie chyba osiąga apogeum. 
Specyfika męskiego ubioru pojawiła się w wypowiedziach narratorów, którzy tłumaczyli:

U mężczyzn to w ogóle inaczej z tym ubiorem. Spodnie, koszula i ot caty ubiór; nie ma tylu rodzajów ubrania jak u kobiet. I teraz te garnitury i te spodnie, koszule wygladaja naprawdę dobrze; lepiej. Nie sa już takie duże; garnitury też występuja i jasne i najważniejsze, żeby byto czysto i no tak... schludnie [M, 72].

A tak mówiła o tym jedna $z$ badanych kobiet:

U panów to nie ma problemu z ubraniem, panowie moga nosić i jeansy do wielkiej starości, to zależy jak który się starzeje. Ale powinna być jakaś koszulka przyzwoita, też obowiazuje, sweterek. I spodnie i po kłopocie [K, 90].

Zapytałam też badanych, co nie podoba się im w ubiorze dzisiejszej seniorki? Na to pytanie odpowiedzi były bardziej zróżnicowanie (wykres 3). Kobietom $(76,7 \%)$ częściej niż mężczyznom $(61,4 \%)$ nie podoba się zaniedbywanie ubioru i niechlujstwo. Seniorki (60\%) były też dużo bardziej krytyczne niż seniorzy (22,7\%) wobec długości i obszerności elemen-

Wykres 3

Co się Panu(i) nie podoba w tym, jak dzisiaj ubierają się kobiety-seniorki? (w \%)

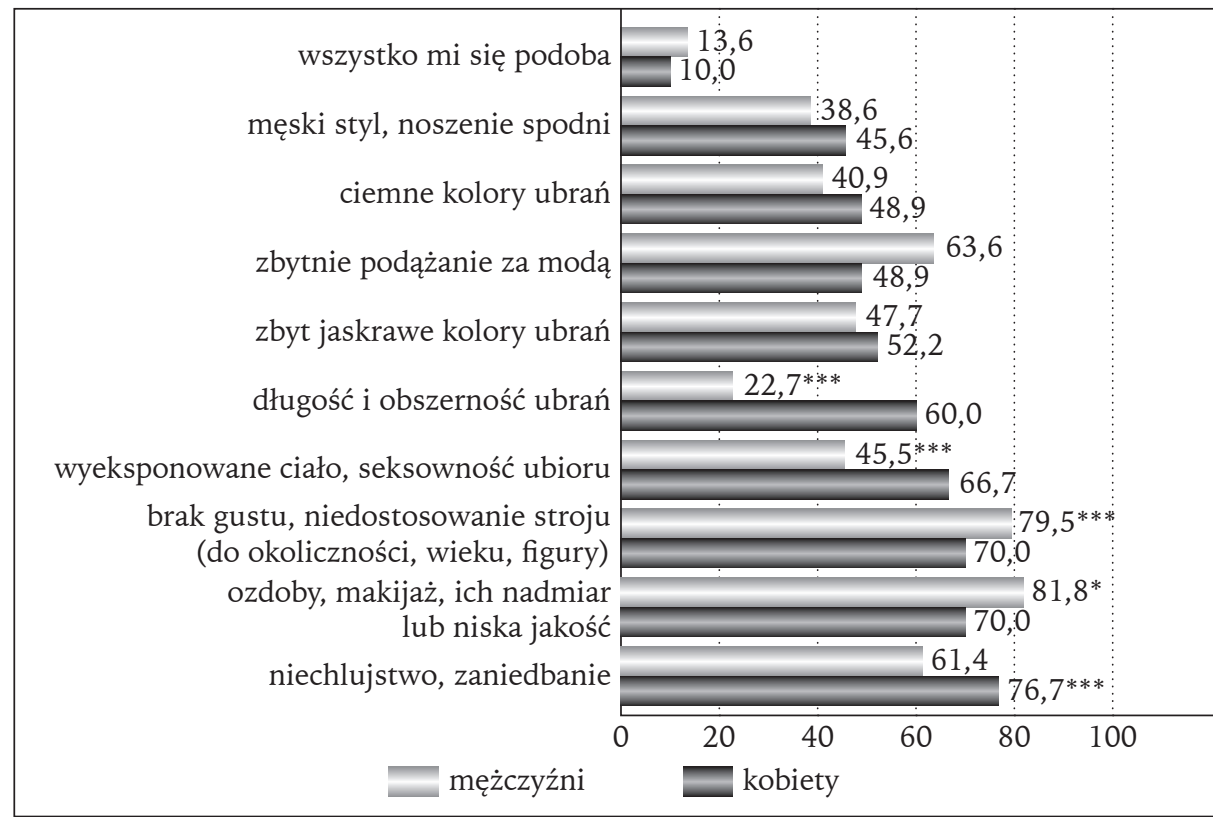

${ }^{*} \mathrm{p}<0,05$

$* * * \mathrm{p}<0,001$

Źródło: badania własne. 
tów garderoby ich rówieśnic; wobec wyeksponowania ciała i seksowności ubioru (K: 66,7\%; M: 45,5\%); wobec jego ciemnej kolorystyki (K: 48,9\%; M: 40,9\%). Nie podoba się im tównież męski styl, czyli noszenie spodni przez kobiety (K: 45,6\%; M: 38,6\%). Z odpowiedzi udzielanych przez badanych mężczyzn wynika, że ich zdaniem wiele do życzenia pozostawiają makijaż czy ozdoby (ich nadmiar lub niska jakość) stosowane przez kobiety w starszym wieku (M: 81,8\%; K: 70\%), brak gustu i niestosowność ubioru do okoliczności, wieku czy figury (M: 79,5\%; K: 70\%), a także zbytnie podążanie za modą (M: 63,6\%; K: 48,9\%).

Wskazania moich ankietowanych są zbieżne $z$ wynikami badań przeprowadzonych przez Aleksandrę Perchlę-Włosik z zespołem, które dotyczyły zachowań konsumenckich i zainteresowania modą kobiet w różnym wieku. „Wygodne pięćdziesięcio- i sześćdziesięciolatki” — jak Perchla-Włosik określa respondentki - uwzględniające wieloletnie doświadczanie swojego ciała i zachodzące w nim zmiany, są zwolenniczkami takich elementów garderoby, które pasują do ich figury i wieku, nie eksponują ciała, a raczej tuszują jego niedoskonałości, stosownie do sylwetki i stylu. Za jedno z najważniejszych kryteriów wyboru odzieży - w porównaniu z młodszymi kobietami - uznają wygodę. Zdaniem badaczki „poszukują przede wszystkim komfortu w noszeniu produktów modowych - na rzecz wygody są w stanie zrezygnować z modnych ubrań" (Perchla-Włosik 2019, s. 143; por. Kall i in. 2018).

Respondenci zapytani o to, co nie podoba się im w sposobie ubierania się dzisiejszego mężczyzny w starszym wieku (wykres 4), byli zgodni tylko co do jednej cechy - zaniedbywanie ubioru i jego niechlujny wygląd. Kobietom częściej niż mężczyznom przeszkadza ubiór wyzywający, ekstrawagancki (K: 57,8\%; M: 54,6\%) oraz wyeksponowanie ciała (K: 53,3\%; M: 36,4\%). Zatem to, co tak bardzo podoba się seniorom, czyli eksponowanie ciała, bardzo nie podoba się seniorkom. Kobiety były też dużo bardziej krytyczne wobec obszernego i luźnego stroju swoich rówieśników (K: 53,3\%; M: 25\%), wobec jego nijakości (K: 53,3\%; M: 36,4\%), ciemnych kolorów (K: 48,9\%; M: 40,9\%) i co zaskakujące - wobec zbytniego podążania starszych mężczyzn za modą (K: 51,1\%; M: 36,4\%).

To ciekawe, ogólnie rzecz biorąc badanym podoba się modne ubieranie się ich rówieśników i rówieśnic, ale już zbytnie podążanie za modą budzi ich zastrzeżenia. Kobiety dają przyzwolenie seniorkom na podążanie za modą, ale wobec takich samych zachowań seniorów są już bardziej krytyczne. Identycznie jest w przypadku mężczyzn. $Z$ badań wynika, że nie przeszkadza im bardzo modne „noszenie się” ich rówieśników, ale mają zastrzeżenia co do podobnych zachowań przedstawicielek płci przeciwnej. 
SIMMLOWSKA KONCEPCJA MODY A UBIÓR WSPÓŁCZESNYCH SENIOREK I SENIORÓW 169

Wykres 4

Co się Panu(i) nie podoba w tym, jak dzisiaj ubierają się mężczyźni-seniorzy? (w \%)

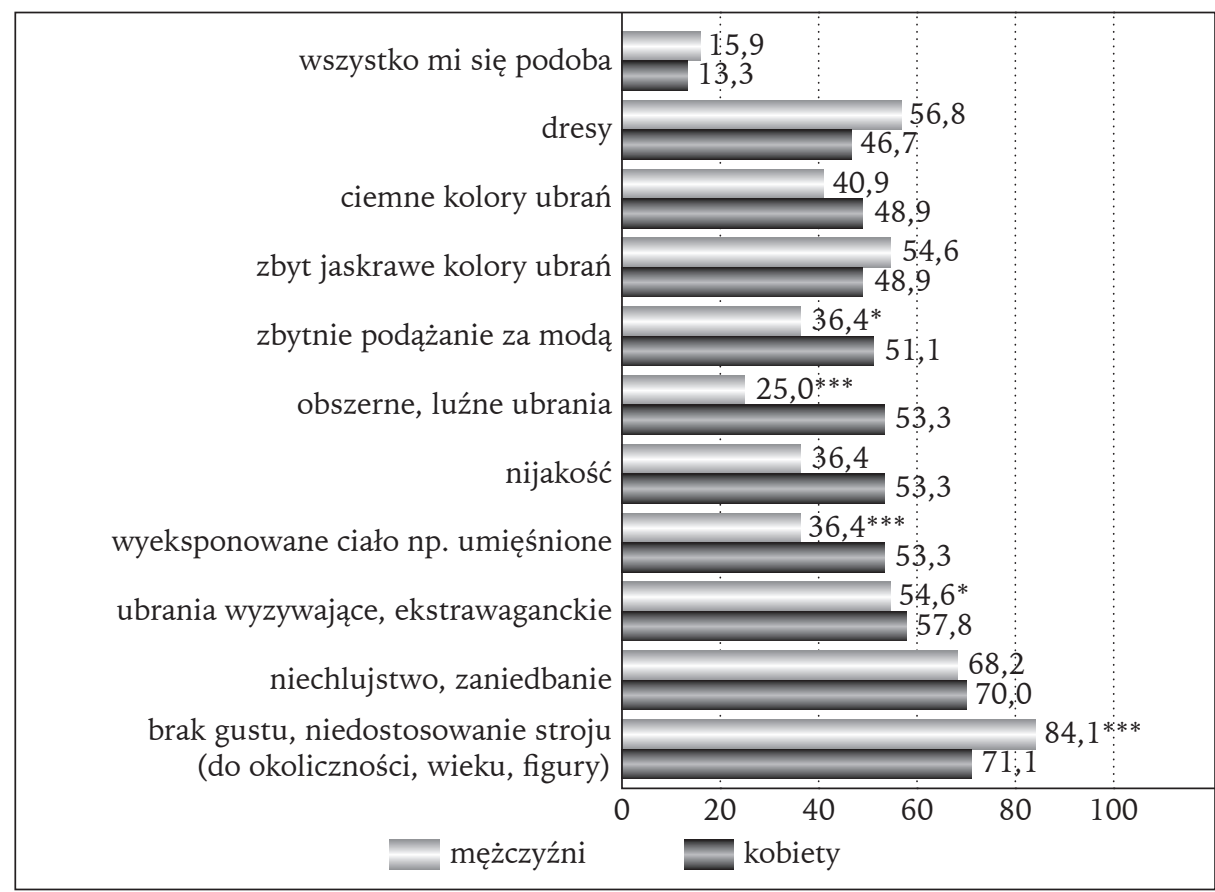

${ }^{*} \mathrm{p}<0,01 \quad{ }^{* * *} \mathrm{p}<0,001$

Źródło: badania własne.

Czy zbytnie podążanie za modą to zbyt odważne stylizacje? Jak na przykład kampania bielizny Calvina Kleina z 73-letnią modelką Lauren Hutton w roli głównej. Albo może podążanie za wezwaniem 84-letniej byłej modelki Dorrie Jacobson, która nawołuje na swoim blogu: „noście co chcecie! Nie ma niczego takiego, co nie przystoi kobiecie w pewnym wieku. Czasy się zmieniły. Dojrzałe fashionistki nie mają zamiaru znikać ludziom z oczu tylko dlatego, że skończyły 60 czy 70 lat. Nie chcą wkładać bezkształtnych ubrań, by jak najlepiej wtopić się w tło" ${ }^{4}$.

Obserwując polską rzeczywistość, dostrzegamy przykłady kampanii pro-age ( $\mathrm{w}$ obszarze mody, kosmetyki czy kosmetologii) będące niejako odpowiedzią na wezwanie Jacobson. Mamy też w Polsce blogerki Plus Age (np. Krystyna Bałakier), które zaznajamiają osoby starsze z tajnikami współczesnej mody i udowadniają, że inspiracje można czerpać w każdym

\footnotetext{
${ }^{4}$ http://www.seniorstylebible.com
} 
wieku. Czy przytoczone przykłady są tym, co badani seniorzy uważają za zbytnie podążanie za modą? Za zbyt daleko posunięte naśladownictwo młodszych pokoleń? A może w ich opinii jest to przejaw zbyt odważnego pokazywania swej odrębności? Wydaje się, że wielu polskich seniorów nie jest gotowych na rewolucję $\mathrm{w}$ zakresie ubioru, a tym samym mogliby przyznać rację Simmlowi, który twierdził, że „moda komunikuje przynależność do «ludzi równych sobie», ale stanowi przymiot wyższych warstw i stanów, które dzięki niej można odróżnić od stanów niższych. A zatem to, co nowe, istotnie wyróżnia tych, którzy znajdują się na wyższej pozycji w hierarchii społecznej" (zob. Perchla-Włosik 2019, s. 17). Choć krytycy myśli Simmla zwracają uwagę na obserwowany dziś wielokierunkowy przepływ mody w miejsce wertykalnego, trudno nie dostrzec, że seniorzy, zwłaszcza ci starsi, mogą odczuwać „modową wyższość” ludzi młodych. $\mathrm{Na}$ podstawie prowadzonych z nimi rozmów i obserwacji wnioskuję, że młodsi seniorzy, czyli osoby dopiero wkraczające w wiek emerytalny, częściej zdecydują się na odważne stylizacje, uważając je za wartościowe, więc godne naśladowania albo służące pokazaniu ich osobowości jeszcze nie nadgryzionej zębem czasu. Jednak ci starsi, na przykład urodzeni w okresie międzywojennym, oraz mężczyźni częściej niż kobiety bardziej niż za modą podążają raczej za the age-ordering of clothes, bo w obszarze mody nie czują się równi ludziom młodym. Świadczyć może o tym następujący komentarz jednego z mężczyzn:

Uważam, że i tak już się człowiek nie odmtodzi, bo wszystko jest na wizji. Co by ktoś nie robit to i tak nie ukryje wieku. I modny strój, no ten taki kolorowy, jak to dziś widać na ulicach, nic nie pomoże. A tylko człowiek zrobi z siebie pośmiewisko $[\mathrm{M}, 81]$.

Ogólnie rzecz biorąc, mężczyźni są mniej krytyczni niż kobiety wobec sposobu ubierania się męskich rówieśników. Nie podobają się im trzy rzeczy: brak gustu, niedostosowanie stroju do okoliczności, wieku czy sylwetki (M: 84,1\%; K: 71,1\%); zbyt jaskrawe kolory ubrań (M: 54,6\%; K: 48,9\%) oraz noszenie dresów (M: 56,8\%; K: 46,7\%). „Garnitur — pisze Grażyna Bokszańska (2004, s. 69) - symbolizuje tradycjonalizm, hierarchię, konformizm i oczywiście pieniądze. Mężczyzna ubrany w taki garnitur wysyła wyraźne sygnały o swojej pozycji i domaga się należnego dla niej respektu". Czy opinia ta może stanowić wytłumaczenie niechęci badanych mężczyzn wobec noszenia dresów przez ich rówieśników? Wydaje się to prawdopodobne. Fragment jednego z wywiadów potwierdza to wnioskowanie i zwraca uwagę na jeszcze jeden aspekt męskiego przywiązania do tradycyjnych wzorców: 
Kiedyś nawet latem $w$ długich spodniach się chodziło. Jak bytem młody to żaden facet nie nosit krótkich spodni. I dresy to rzadkość byta. W niedziele do kościoła też idę $w$ długich. Kiedyś sobie nie wyobrażałem, że do kościoła $w$ jeansach można iść. A teraz chodza do kościoła $w$ jeansach. Do kościoła to ja zawsze w garniturze, albo $w$ spodniach na kant. Osoby w moim wieku do kościoła to większość jednak ubieraja się $w$ normalnych spodniach, choć zdarza się że przyjdzie $w$ jeansach, ale to mniej. Raczej w normalnych spodniach, materiałowych [M, 81].

Czyli nie tylko dresy nie pasują seniorowi, ale według narratora nawet jeansy? Pozostali panowie byli mniej krytyczni i nie mieli nic przeciwko noszeniu jeansów przez rówieśników.

Ja tam nie mam nic przeciwko jeansom. Jeansy, to jeansy, oby czyste i nieśmierdzace, to jest już dla mnie super — stwierdził jeden $\mathrm{z}$ narratorów [M, 64].

Badane seniorki też były w tym zakresie bardziej nowoczesne, a może i modne? Jedna $z$ nich powiedziała:

Dawniej jeansów nie było to panowie nosili spodnie, ale w różnym kolorze. A teraz sa jeansy, i też są okej. I jak jeszcze te rurki mężczyzna założy, to już w ogóle fajnie $[\mathrm{K}, 79]$.

\section{GRANICE NAŚLADOWNICTWA I ODRĘBNOŚCI W ZAKRESIE UBIORU Z KOBIECEJ I MĘSKIEJ PERSPEKTYWY}

W literaturze przedmiotu odnajdziemy wiele publikacji, w których czytamy o pozytywnych następstwach sposobu funkcjonowania seniorów w warunkach społeczeństwa konsumpcyjnego i związanej z tym juwenalizacji kultury, co przybiera postać społeczeństwa „młodniejącego” (Twigg 2007, 2013; Konieczna-Woźniak 2012; Giddens 2009). Strategie odmładzające pozwalają bowiem osobom starszym oswoić starość, przezwyciężyć codzienne troski związane $z$ mniejszą sprawnością czy też wyrazić tkwiącą w nich młodość i tym samym przybliżyć się do ludzi młodszych (Kolibabska 2009, s. 62). Zadałam więc badanym pytania, które miały pomóc $\mathrm{w}$ rozstrzygnięciu, czy treści zawarte w publikacjach to tylko teoria, czy może praktyka? W jaki sposób funkcjonowanie w „młodniejącym” społeczeństwie wpływa na sposób ubierania się seniorów oraz na ich poglądy w tym zakresie? Czy badani dostrzegają zmianę w wyglądzie osób starszych? Jeśli tak, to jak ją oceniają?

Ankietowani pozytywnie wypowiadają się na temat odmładzania się dzisiejszych seniorek i seniorów przez dobór odpowiedniego ubioru.

Wydaje się, że głosy kobiet i mężczyzn są w tym wypadku bardzo podobne (wykres 5). Respondenci są też zgodni (ponad 90\% wskazań w obu 
Ocena ubioru współczesnych seniorek i seniorów (w \%)

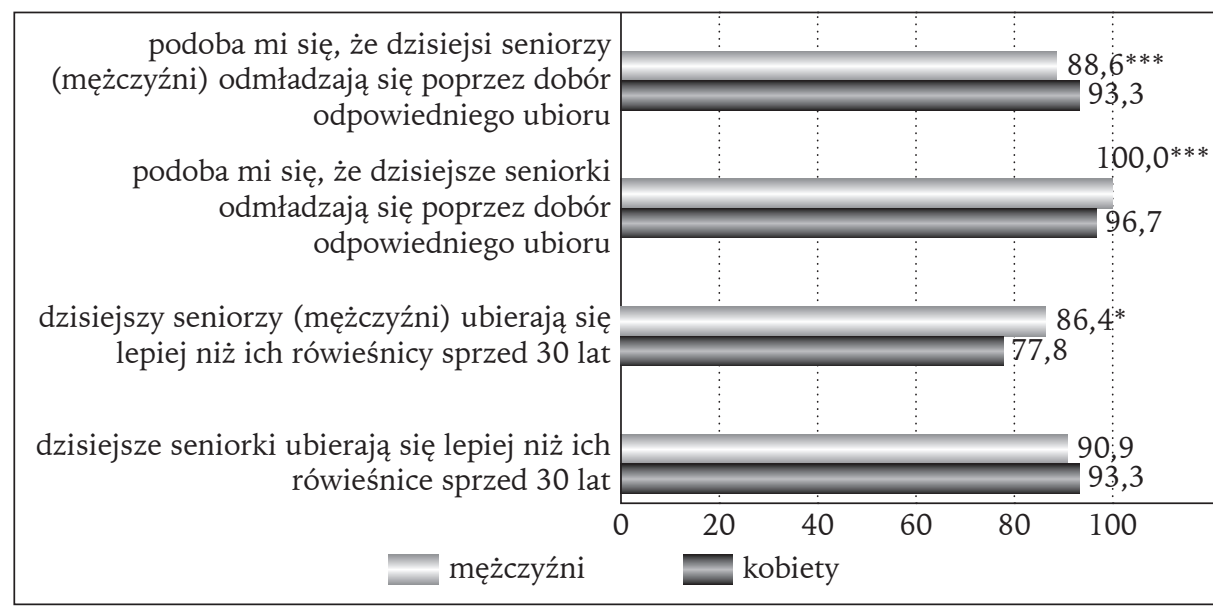

${ }^{*} \mathrm{p}<0,05 \quad * * * \mathrm{p}<0,001$

Źródło: badania własne.

grupach) co do tego, że dzisiejsze seniorki ubierają się lepiej niż ich rówieśnice sprzed trzydziestu lat. Jeśli zaś chodzi o ocenę ubioru starszych mężczyzn - w porównaniu do sytuacji sprzed trzech dekad - to badani seniorzy $(86,4 \%)$ częściej niż seniorki $(77,8 \%)$ dostrzegają pozytywną zmianę. Wyniki ankiety znajdują też potwierdzenie $w$ wypowiedziach rozmówców. Jedna $z$ kobiet powiedziała:

Seniorzy ubieraja się dziś zupetnie inaczej niż seniorzy 20-30 lat temu. Teraz jak zauważyłam osoba starsza nawet do sklepu przychodzi bardzo elegancko ubrana. Bo kiedyś kojarzyto się starszq osobę, taka babcię, która ma dtuga spódnicę, chustkę na głowie i z laseczka chodzita. Teraz te stare osoby, czy maja 70 lat, 80 czy 60-parę, jeśli maja dobra kondycję to chodza podmalowane, atrakcyjne i dbaja o siebie. A poprzednio jak pamiętam, nasze ciotki czy babcie, to byty faktycznie takie babcie [K, 69].

Oto wypowiedź innej narratorki:

Ubiór jak jest nieodpowiedni to bardzo postarza człowieka, a jeszcze jak ktoś jest bardzo chudy to też postarza [K, 71].

Podobne wnioski płyną z badań Julii Twigg $(2007,2013)$ czy Kathleen Slevin (2010). Seniorzy, z którymi rozmawiały badaczki, tłumaczyli swoje zainteresowanie modą głównie tym, że chcą wiedzieć, jakie ubrania nosić, aby nieco oszukać metrykę, ale nie traktują tej praktyki jako obciążenia. Wyznali, że wygląd jest dla nich ważny i dlatego stanowi przedmiot ich 
nieustannej pracy, bo przecież $\mathrm{w}$ dzisiejszym świecie nikomu nie przysługuje w tym zakresie taryfa ulgowa - wszyscy walczą o piękne ciało (Slevin 2010). Z kolei Katarzyna Pawlikowska (2014) zauważa, że historyczno-ekonomiczne uwarunkowania, czyli czasy PRL-u, sprawiły, że tak naprawdę wiele Polek i Polaków dopiero teraz rozpoczyna swoje obycie ze światem mody. Lata dziewięćdziesiąte XX wieku przyniosły dostęp do europejskiej i światowej kultury, więc polskie społeczeństwo coraz bardziej zaczyna ubierać się w sposób wyrażający osobowość. Dla wielu wygląd jest przedmiotem zabawy, daje radość, służy podkreśleniu statusu społecznego. Tempo zmian zachodzących w Polsce dotyka ludzi w różnym stopniu i wydaje się, że starsi są tego najlepszym przykładem, stanowiąc heterogeniczną pod tym względem kategorię społeczną. Poglądy wygłaszane przez moich rozmówców skłaniają do wniosku, że osoby w wieku 60-70 lat często podchodzą do mody w sposób wskazany przez Pawlikowską - wykorzystują ją do wyrażenia własnej osobowości czy, w języku Simmla, odrębności. Widać to na ulicach naszych miast.

Simmlowską koncepcję mody, a dokładniej jego spostrzeżenia dotyczące zależności między modą a płcią, chciałabym wykorzystać jako tło jeszcze innego wątku, który pojawił się w moich badaniach. Podczas jednego z wywiadów usłyszałam:

Dużo się zmienia $w$ ubiorze i wygladzie seniorów, ale ja nie widziatem jeszcze $w$ mieście na przykład dziadka $w$ niebieskich spodniach $i$ czerwonych skarpetkach, chyba że jakiś trzepnięty jest to ten... Jak się pojedzie na zachód to widać, ale w Polsce gdyby taki wyszedt dziadek, to sa dwie opcje — albo ma pieniażki i ma wszystko gdzieś, albo ma coś pod kopułą nie tak. W Polsce jeszcze nie widziałem takiego dziadka [M, 75].

Wypowiedź seniora sugeruje, że starsi mężczyźni w mniejszym stopniu niż kobiety wykazują zainteresowanie modą. Czy zatem rzadziej wykorzystują ją do podkreślenia swej odrębności? Czy w kwestii wyglądu i ubioru są bardziej zachowawczy? Odpowiedź na tak sformułowane pytania częściowo możemy uzyskać analizując rozkład uzyskanych danych (wykres 6).

Tadeusz Czekalski w tomie Obyczaje w Polsce (2008, s. 364) tak charakteryzuje starość lat siedemdziesiątych: „Polski próg starości kojarzono zwykle $z$ wiekiem emerytalnym, czyli w większości wypadków z siódmą dekadą życia. Presja obyczajowa wywierana na ludzi w podeszłym wieku, szczególnie w rodzinach wiejskich i małomiasteczkowych, określała dopuszczalny styl ubierania się i utrudniała zawieranie nowych związków". Autor niestety nie precyzuje, co oznacza ów dopuszczalny styl ubierania się, ale można przypuszczać, że chodzi o skromność ubioru i jego dosto- 
Czy podoba się Panu(i) czy też nie, że obecnie można spotkać na ulicy... (w \%)

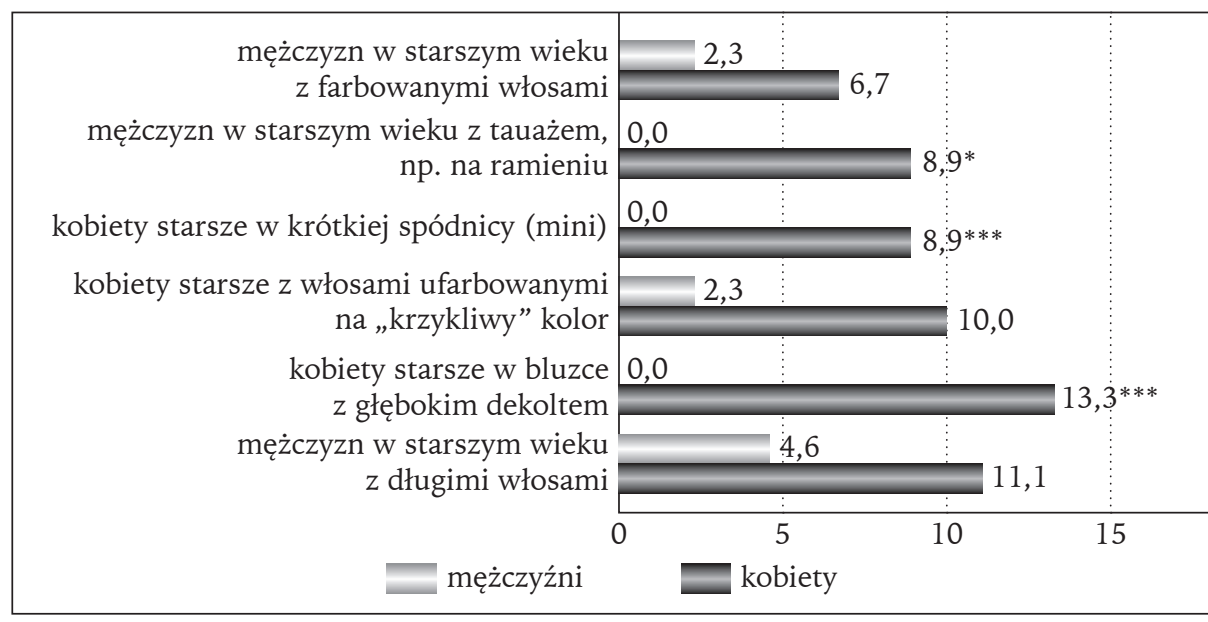

${ }^{*} \mathrm{p}<0,05 \quad * * * \mathrm{p}<0,001$

Źródło: badania własne.

Na wykresie przedstawiono wyłącznie odpowiedzi twierdzące.

sowanie do wieku. Gdy rozpatrujemy uzyskane dane, nasuwa się wniosek: the age-ordering of clothes wciąż obowiązuje. Seniorzy dość wybiórczo przyjmują nowe normy i proponowany kult młodości jako sposób egzystencji współczesnego człowieka (Rejakowa 2010, s. 16). Żadnemu z badanych respondentów płci męskiej nie podoba się to, że na ulicy można dziś spotkać starsze kobiety w bluzce z głębokim dekoltem (13,3\% badanych kobiet nie ma nic przeciwko takiemu widokowi), seniorki w spódnicy mini (8,9\% respondentek popiera to) czy starszych mężczyzn z tatuażem $(8,9 \%$ seniorek nie ma nic przeciwko temu). Co prawda, część mężczyzn pozytywnie zaopiniowała na przykład noszenie przez starszych panów długich włosów (M: 4,6\%; K: 11,1\%) czy ich farbowanie (M: 2,3\%; K: 6,7\%), ale zauważalna jest duża dysproporcja między stopniem poparcia takich praktyk przez badane seniorki i seniorów.

Zaproponowana w 1965 roku przez angielską projektantkę Mary Quant spódniczka mini stała się symbolem istotnych zmian obyczajowych i emancypacji kobiet, podobnie jak późniejsze głębokie dekolty Kaliny Jędrusik - polskiej odpowiedniczki Marilyn Monroe. Przypomnijmy, że w latach sześćdziesiątych pojawiła się też rola człowieka młodego - modnego i zmiennego. Wydaje się, że opinie badanych kobiet są przejawem ich większego niż u mężczyzn przyzwolenia na naśladownictwo ludzi młodych 
przez osoby starsze w zakresie ubioru — choć przyznać należy, że ów poziom przyzwolenia kobiet jest niski. Czy wskazania mężczyzn ujawniają zakorzeniony $\mathrm{w}$ ich świadomości the age-ordering of clothes? Czy spódniczka mini lub głębokie dekolty to ich zdaniem prawo młodości? A przecież o czym pisałam wyżej - mężczyznom podobało się wyeksponowane ciało i seksowność kobiecego ubioru, a kobiety wypowiadały się na ten temat zupełnie odwrotnie.

Jeśli zaś chodzi o tatuaże, to warto zaznaczyć, że czasach PRL-u kojarzyły się one głównie ze światem przestępczym. Spotykało się je na przedramieniu więźniów albo marynarzy. Być może stąd niechęć starszych mężczyzn wobec takiego „znakowania” ciała przez rówieśników. Z kolei długie włosy w „tamtych czasach” często były podsumowywane powiedzeniem „długie włosy — rozum krótki”. Być może utkwiło ono w pamięci seniorów i dlatego nie podoba im się taka fryzura. Podobnie jest z malowaniem włosów przez mężczyzn w podeszłym wieku. Tak wypowiedział się na ten temat jeden $z$ badanych seniorów:

Ja to jestem przeciw; uważam, że człowiek jest jaki jest, starzeje się $i$ jest to proces normalny; naturalny proces. I nie wyobrażam sobie, żebym ja na przykład farbowat sobie wtosy. Kobiety to co innego nie, ale ja? Sa nawet mężczyźni, którzy operacje plastyczne sobie robia, ale sobie tego nie wyobrażam. Takim się urodzitem i taki chce umrzé́ $[\mathrm{M}, 79]$.

Inny komentarz, też z ust mężczyzny:

Mi się tatuaże nie podobają. I $z$ dlugimi włosami to też nie. Jak komuś to potrzebne, to niech sobie robi albo nosi kucyki. Ja tego nie lubię [M, 66].

Opinie badanych są zatem bardzo zróżnicowane, a czasem nawet sprzeczne. Zagraniczna literatura przedmiotu również obrazuje bardzo różne stanowiska ludzi starych wobec analizowanych tu treści (np. Barnard 1996; Hurd Clarke 2001, 2018; Rhode 2010; Catrinel, Flick 2016). Za Fredem Davisem (1989, s. 338) można przyjąć, że ambiwalencja badanych w stosunku do mody i sposobu ubierania się wynika ze sprzeczności obecnych w kulturze współczesnej, w której normy i wartości ulegają zmianie w taki sposób, że wartości zinternalizowane podczas socjalizacji nie pokrywają się z nowymi wzorcami. Doświadczają tego zwłaszcza seniorzy. Człowiek dąży do równowagi między socjalizacją a indywidualizacją, co w odniesieniu do koncepcji Simmla przekłada się na poszukiwanie równowagi między odróżnianiem się i upodabnianiem w ubiorze, czyli do pogodzenia zewnętrznych oczekiwań, jednostkowych dążeń oraz koncepcji siebie. Bogna Dowgiałło (2015, s. 225-230) na podstawie badań przeprowadzonych wśród osób kupujących odzież w lumpeksach „Second Life” 
stwierdziła, że pogodzenie odróżnienia $\mathrm{z}$ upodobnieniem może dokonać się między innymi dzięki zachowaniu ciągłej dynamiki ubraniowych wyborów. Opisywane tu badania mogą sugerować, że stopniowo zachodzi wśród seniorów proces poszukiwania samego siebie zarówno za sprawą podobieństwa do innych, jak i odrębności od nich. Wydaje się jednak, że przebiega on łatwiej i sprawniej wśród młodszych seniorów i kobiet rozumiejących, że „zupełny brak podobieństwa rodzi uczucie wyobcowania, ale odróżnienie jest konieczne, by podobieństwu nadać sens" (Dowgiałło 2015, s. 226).

\section{ZAKOŃCZENIE}

Kluczowe w koncepcji mody Georga Simmla idee naśladownictwa i odrębności trafnie oddają jej istotę, zwłaszcza gdy analizujemy ubiór człowieka. Dzięki doskonałej intuicji Simmla jego spostrzeżenia nie tracą aktualności. Wykorzystałam je jako punkt odniesienia w analizie opinii osób starszych na temat ubioru ich rówieśników.

Simmel uważał, że naśladownictwo jest zachowaniem częstszym wśród kobiet niż wśród mężczyzn. Połączenie tej myśli z założeniem Petera Braunsteina i Michaela Doyle (2002, s. 24), że „bycie modnym oznacza bycie młodym" oraz z tendencjami charakterystycznymi dla społeczeństwa „młodniejącego” (Giddens 2009) sprawia, iż wydaje się, że Simmlowska koncepcja pasuje do sytuacji starszych kobiet. Badane seniorki częściej niż mężczyźni opowiadały się za modnym ubiorem rówieśników i rówieśnic oraz bardziej niż mężczyznom podobały się im żywe kolory ubrań w miejsce stonowanych. Kobiety też częściej niż mężczyźni wskazywały, że seniorki mogą nosić spódnice mini albo bluzki z głębokim dekoltem. Preferencje seniorek dla tego typu stylizacji można zinterpretować jako ich zgodę na naśladowanie sposobu ubierania się młodszych pokoleń i na powolną zmianę dotychczasowego the age-ordering of clothes. Opinie badanych mężczyzn częściej sugerowały ich przywiązanie do dotychczas obowiązującego porządku ubioru.

Obok idei naśladownictwa istotna jest też idea odrębności, która stanowi — zdaniem Simmla - element składowy mody służący kobietom do zaakcentowania swej wyjątkowości głównie wtedy, gdy w innych obszarach nie znajdą możliwości zaspokojenia. Simmel (2007b, s. 13) stwierdził nawet: „moda stanowi dla kobiet w pewnym sensie element zastępczy pozycji w danym zawodzie". Starsze kobiety etap aktywności zawodowej mają już za sobą, więc skoro w tej przestrzeni nie znajdują zaspokojenia, to może posłuży im do tego oryginalność ubioru? Z przeprowadzonych prze- 
ze mnie badań wynika, że owszem, taka strategia może się sprawdzić, ale na obecnym etapie rozpoznania zagadnienia jestem skłonna uznać, że niewiele seniorek będzie ją praktykować. Badani zalecali rozsądne podążanie za tym, co jest „na czasie”. $Z$ wypowiedzi narratorów — zarówno mężczyzn, jak i kobiet - wynika, że zbyt odważne, modne stylizacje osobom starszym nie pasują i mogą narazić je na śmieszność. Umiarkowane naśladownictwo młodszych pokoleń zdaniem badanych jest bardziej wskazane niż używanie mody jako narzędzia służącego pokazaniu swej odrębności. Takie poglądy częściej głosili starsi seniorzy niż ci dopiero wkraczający w ostatni etap życia. Obok płci ważny był zatem wiek badanych. Młodsi seniorzy i seniorki mają, jak się wydaje, więcej odwagi, by przełamywać the age-ordering of clothes.

Maguelonne Toussaint-Samat (2011, s. 310) napisała: „Materialny kształt ubiorów wynika z możliwości technicznych, jednak jest on także tworem ludzkiego intelektu — przesłaniem estetycznym, osobistym i kulturowym". Wydaje się, że intelekt ludzki zmierza w stronę upodmiotowienia seniorów i odrzucenia tradycyjnej kultury ich marginalizacji. W jej miejsce proponuje uczynienie ich równoprawnymi członkami społeczeństwa, kreującymi swój wizerunek, w tym swój ubiór, według własnych upodobań. Funkcjonowanie w „młodniejącym” społeczeństwie daje osobom starszym wiele możliwości w tym zakresie. Można sądzić, że badani przez Julię Twigg brytyjscy seniorzy w większym stopniu niż ci mieszkający w Polsce z możliwości tych korzystają. Jednak już wstępne rozpoznanie tematu sugeruje, że i u nas powoli to się zmienia.

Przedstawione badania traktuję jako badania pilotażowe. Według mojej najlepszej wiedzy w polskiej literaturze socjologicznej i gerontologicznej brakuje opracowań poświęconych tematowi mody czy ubioru seniorów. Zainspirowana literaturą zagraniczną postanowiłam rozpocząć diagnozowanie tego zagadnienia wśród osób starszych, z którymi miałam kontakt $\mathrm{w}$ ramach prowadzonych przeze mnie warsztatów. Wiem, że moi badani to szczególna grupa. Są to osoby, które z myślą o sobie i własnym rozwoju chcą zagospodarować czas na emeryturze, więc poszukują aktywności, które mogłyby im to zapewnić. Przypuszczam zatem, że seniorzy wycofani, może seniorzy mieszkający na wsi, mogliby inaczej odpowiadać na pytania $z$ ankiety czy wywiadu. Ważną cechą moich respondentów była otwartość, chęć wzięcia udziału w badaniu i rzetelne do tego podejście. Dzięki temu przeprowadzony pilotaż uważam za udany i pomocny w planowaniu dalszych badań jakościowych o zasięgu ogólnopolskim. Planuję przeprowadzenie wywiadów indywidualnych $z$ seniorami w różnych kategoriach wiekowych, kobietami i mężczyznami, a także z mieszkańcami miasta i wsi. 
Planuję również zorganizowanie zogniskowanych wywiadów grupowych $z$ dwiema grupami seniorów, to znaczy $z$ angażującymi się $\mathrm{w}$ różne działania społeczne oraz z niezaangażowanymi. Podczas wywiadów grupowych chciałabym wykorzystać materiały wizualne, takie jak blogi prowadzone przez starszych wiekiem infuenserów, którzy ukazują, jak stylem i ubiorem bawią się osoby starsze (np. Accidental Icon, Advanced Style). Obserwacja reakcji seniorów na prezentowane im zdjęcia czy filmy oraz poznanie ich opinii na temat tego, co widzą, może stanowić interesujące rozpoznanie niszowego zagadnienia, jakim jest znaczenie mody dla seniorów.

\section{BIBLIOGRAFIA}

Barnard Malcolm, 1996, Fashion as Communication, Routledge, London.

Blumer Herbert, 1969, From Class Differentiation to Collective Selection, „Sociological Quarterly”, t. 3, s. 275-291.

Bokszańska Grażyna, 2004, Ubiór w teatrze życia społecznego, Wydawnictwo Politechniki Łódzkiej, Łódź.

Braunstein Peter, Doyle Michael, 2002, Imagine Nation: The American Counterculture of the 1960s and '70s, Routledge, London.

Catrinel Craciun, Flick Uwe, 2016, Aging in Precarious Times: Exploring the Role of Gender in Shaping Views on Aging, "Journal of Women and Aging”, t. 28(6), s. 530-539.

Czekalski Tadeusz, 2008, Czasy wspótczesne, w: Andrzej Chwalba (red.), Obyczaje w Polsce. Od średniowiecza do czasów wspótczesnych, Wydawnictwo Naukowe PWN, Warszawa.

Beauvoir Simone de, 2003, Druga pteć, tłum. Gabriela Mycielska, Maria Leśniewska, Wydawnictwo Czarna Owca, Warszawa.

Davis Fred, 1989, Fashion, Culture and Identity, University of Chicago Press, Chicago.

Dowgiałło Bogna, 2015, Ubieranie się jako forma uspołecznienia. O aktualności koncepcji mody Georga Simmla, Wydawnictwo Uniwersytetu Gdańskiego, Gdańsk.

Gajewska Agnieszka, 2008, Hasto: feminizm, Wydawnictwo Poznańskie, Poznań.

Gibson Pamela, 2000, "No One Expects Me Anywhere": Invisible Women, Ageing and the Fashion Industry, w: Stella Bruzzi, Pamela Ch. Gibson (red.), Fashion Cultures: Theories, Explorations and Analysis, Routledge, London.

Giddens Anthony, 2009, Europa w epoce globalnej, tłum. Magdalena Klimowicz, Miłosz Habura, Wydawnictwo Naukowe PWN, Warszawa.

Gilleard Chris, Higgs Paul, 2000, Culture of Ageing: Self, Citizen and the Body, Prentice Hall, London.

Greer Germaine, 1991, The Change: Women, Ageing and the Menopause, Hamish Hamilton, London.

Gromkowska-Melosik Agnieszka, 2012, Ciało, moda i tożsamość kobiety epoki wiktoriańskiej dyskursy piękna i przemocy, „Kultura — Społeczeństwo - Edukacja”, nr 2, s. 17-30.

Gromkowska-Melosik Agnieszka, 2013, Kobieta epoki wiktoriańskiej. Tożsamość, ciało i medykalizacja, Impuls, Kraków.

Hurd Clarke Laura, 2001, Older Women's Bodies and the Self: The Construction of Identity in Later Life, „Canadian Review of Sociology and Anthropology”, t. 38(4), s. 441-464. 
Hurd Clarke Laura, 2018, Women, Aging, and Beauty Culture: Navigating the Social Perils of Looking Old, „Journal of the American Society on Aging”, t. 41(4), s. 104-108.

Jeffreys Sheila, 2005, Beauty and Misogyny: Harmful Cultural Practices in the West, Routledge, London.

Kall Jacek, Perchla-Włosik Aleksandra, Raciniewska Alicja, Semperuch-Krzemińska Katarzyna, 2018, Marka modowa. Jak zrozumieć konsumenta mody $i$ stworzyć markę szyta na miarę?, Polskie Wydawnictwo Ekonomiczne, Warszawa.

Kapciak Alina, 1999, Moda, w: Encyklopedia socjologii, t. 2, Oficyna Naukowa, Warszawa.

Kolibabska Katarzyna, 2009, Trwanie w młodości. Strategie odmładzające stosowane przez ludzi starszych $z$ warszawskiego centrum ustug socjalnych, w: Honorata Jakubowska, Alicja Raciniewska, Łukasz Rogowski (red.), Patrząc na starość, Wydawnictwo Naukowe UAM, Poznań.

Konieczna-Woźniak Renata, 2012, „Odmłodzona” starość - implikacje podmiotowe i społecznej, „Studia Edukacyjne”, nr 2, s. 249-262.

Linkiewicz Ewa, 2014, Moda jako czynnik sprzyjajacy zmianom spoteczno-kulturowym. Estetyczny aspekt rzeczywistości, w: Wojciech Bobrowicz, Dariusz Kubinowski, Zbigniew Pakuła (red.), Moda w kulturze, sztuce i edukacji, Wydawnictwo UMCS, Lublin.

Lipovetsky Gilles, 2008, Postępująca zmian istoty tego, co społeczne, w: Piotr Sztompka, Małgorzata Bogunia-Borowska (red.), Socjologia codzienności, Znak, Kraków.

Łaciak Beata, 2006, Obyczaje dotyczace ciała w Polsce okresu transformacji, w: Jacek Maria Kurczewski i in. (red.), Praktyki cielesne, Trio, Warszawa.

Pawlikowska Katarzyna, 2014, Modne Polki, czyli prawie każda zna się na trendach, w: Katarzyna Pawlikowska, Dominika Maison, Polki. Spetnione profesjonalistki, rodzinne panie domu czy obywatelki świata, Wydawnictwa Uniwersytetu Warszawskiego, Warszawa.

Perchla-Włosik Aleksandra, 2019, Moda a społeczeństwo konsumpcyjne. Społeczne znaczenie mody $w$ kreowaniu tożsamości i zachowań konsumenckich, Wydawnictwo Uniwersytetu Wrocławskiego, Wrocław.

Polhemus Ted, 1994, Streetstyle; from Sidewalk to Catwalk, Thames and Hudson, London.

Reckwitz Andreas, 2017, Odkrycie kreatywności. O procesie społecznej estetyzacji, tłum. Katarzyna Kończal, Zofia Sucharska, Narodowe Centrum Kultury, Warszawa.

Rejakowa Bożena, 2010, Kulturowe aspekty mody, Wydawnictwo UMCS, Lublin.

Rhode Deborah, 2010, The Beauty Bias: The Injustice of Appearance in Life and Law, Oxford University Press, New York.

Simmel Georg, 2005, Socjologia, tłum. Małgorzata Łukasiewicz, Wydawnictwo Naukowe PWN, Warszawa.

Simmel Georg, 2006, Most i drzwi. Wybór esejów, tłum. Małgorzata Łukasiewicz, Oficyna Naukowa, Warszawa.

Simmel Georg, 2007a, Filozofia mody, tłum. Sławomir Magala, w: Piotr Sztompka, Marek Kucia (red.). Socjologia. Lektury, Znak, Kraków.

Simmel Georg, 2007b, Filozofia kultury. Wybór esejów, tłum. Wojciech Kunicki, Wydawnictwo Uniwersytetu Jagiellońskiego, Kraków.

Simmel Georg, 2008, Pisma socjologiczne, tłum. Małgorzata Łukasiewicz, Oficyna Naukowa, Warszawa.

Slevin Kathleen, 2010, "If I Had Lots of Money... I'd Have a Body Makeover": Managing the Aging Body, „Social Forces”, t. 88(3), s. 1003-1020. 
Szacki Jerzy, 2003, Historia myśli socjologicznej, Wydawnictwo Naukowe PWN, Warszawa.

Szarota Piotr, 2008, Od skarpetek Tyrmanda do krawata Leppera. Psychologia stroju dla średnio zaawansowanych, Wydawnictwa Akademickie i Profesjonalne, Warszawa.

Szlendak Tomasz, Pietrowicz Krzysztof (red.), 2007, Rozkoszna zaraza: o rzadach mody i kulturze popularnej, Wydawnictwo Uniwersytetu Wrocławskiego, Wrocław.

Toussaint-Samat Maguelonne, 2011, Historia stroju, tłum. Krystyna Szeżyńska-Maćkowiak, Wydawnictwo W.A.B., Warszawa.

Twigg Julia, 2007, Clothing, Age and the Body: A Critical Review, „Ageing \& Society”, t. 27, s. 285-305.

Twigg Julia, 2013, Fashion and Age: Dress, the Body and Later Life, Bloomsbury, London. Williams Dorota, Sołtysiak Grzegorz, 2016, Modny PRL, Świat Książki, Warszawa.

\title{
SIMMEL'S CONCEPT OF FASHION AND THE CLOTHING OF CONTEMPORARY SENIORS: A RESEARCH APPROACH
}

\author{
Emilia Kramkowska \\ (University of Bialystok)
}

\begin{abstract}
The purpose of this article is to draw attention to the undiscussed and yet very interesting issue of fashion and the clothing of senior citizens. The issue is analyzed here in relation to Georg Simmel's concept of fashion and specifically his idea of imitation and distinctiveness inscribed in the fashion system. Simmel seems to indicate that the social order determined by fashion is more often respected by women than by men. Therefore, the issue of fashion and clothing is discussed in relation to the gender of the individual. Age is also important. In her own research among people aged 60 and over (a diagnostic survey and interviews), the author of the article sought answers to the following questions: what do seniors think about the clothing of today's older people? Do they think they dress fashionably-in the sense of following the spirit of modern times, which promotes youth? What determines the way seniors dress in contemporary Poland? The respondents were aware of a change in how seniors dress today and view the change positively. The fashion behavior of seniors is more often approved by women than by men and by younger seniors rather than older ones.
\end{abstract}

key words: clothing, fashion, gender, senior citizens; Georg Simmel

stowa kluczowe: ubiór, moda, płeć, osoby starsze, Georg Simmel 